ELORE (ISSN 1456-3010), vol. $18-2 / 2011$.

Julkaisija: Suomen Kansantietouden Tutkijain Seura ry.

[http://www.elore.fi/arkisto/2_11/hakamies.pdf]

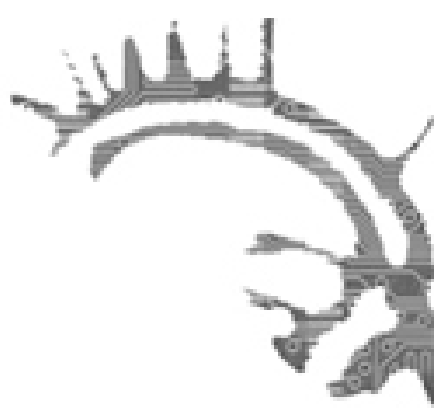

KIRJA-ARVIO

\title{
Tekstien ja laulujen Karjala
}

SUUTARI, PEKKA \& SHIKALOV, YURY (toim.) 2010: Karelia Written and Sung. Representations of Locality in Soviet and Russian Contexts. Helsinki: Kikimora Publications. 280 sivua.

\section{Pekka Hakamies}

Karelia Written and Sung-artikkelijulkaisun taustalla on samanniminen, Suomen Akatemian vuosina 2007-2010 rahoittama projekti, jonka vastuullisena johtajana toimi Pekka Suutari ja tutkijoina joukko silloisen Joensuun yliopiston sekä Petroskoin yliopiston ja Venäjän tiedeakatemian instituutin tutkijoita. Hankkeen tarkoituksena oli selvittää monitahoisesti niitä tapoja (signifying practices), joilla on luotu kulttuurisesti paikallisuutta neuvostovallan alkuajoista jälkisosialistiseen Venäjään. Teoksessa on yhteensä 14 artikkelia kielitieteen, kirjallisuudentutkimuksen, historian ja perinteentutkimuksen alalta. Maantieteellinen kohdistus on Karjalan tasavaltaan ja siihen, miten sitä on tuotettu kirjoittamalla ja laulamalla. Vaikka jotkut kokoelman artikkelit ulottuvat aikatasoltaan menneille vuosisadoille, pääpaino on kuitenkin Neuvostoliiton jälkeisessä ajassa.

Englanninkielisestä nimestään huolimatta teos on kaksikielinen: suomalaisten artikkelit ovat yhtä lukuun ottamatta englanniksi ja venäläisten venäjäksi. Venäjän kielen osuus on ymmärrettävä, koska äidinkielellä on helppo kirjoittaa ja venäjä on kuitenkin yksi maailman laajimmin osatuista kielistä. Se kuitenkin rajaa lukijoiden piiriä maantieteellisesti varsin jyrkästi ja jättää länsimaisen lukijakunnan sivuun. Olisi ollut hyvä, jos artikkeleista olisi edes tiivistelmät toisella kielellä niin, että kieltä osaamaton voisi saada jonkinlaisen käsityksen sisällöstä. Parasta olisi ollut, jos kaikki artikkelit olisi käännetty englanniksi, jotta Karjalan tasavallassa tehtävä tutkimus olisi voinut tulla paremmin tunnetuksi siellä, missä siitä toistaiseksi tiedetään melko vähän. 
Pekka Hakamies: Tekstien ja laulujen Karjala

\section{NÄKYMIÄ KARJALAN KIELEEN}

Vaikka karjalaiset ovat Karjalan tasavallan nimikkokansa, heidän kieleltään puuttuu kirjakielen status. Teoksen kielitieteellisissä artikkeleissa valotetaan monelta kannalta karjalan kielen aseman muutoksia ja yrityksiä luoda kirjakieli. Irma Mullosen artikkeli tuo esiin kielen historiallista taustaa selvittämällä karjalan murteiden muodostumista. Aleksandra Rodionova kirjoittaa karjalan kirjakielen luomiseen liittyneistä ongelmista, joista yksi on ollut kirjaimisto: karjalaa on kirjoitettu sekä kyrillisillä että latinalaisilla aakkosilla. Aakkosten valintakin on riippuvainen siitä, mitä murretta niillä kirjoitetaan: Vienan murteisiin, varsinkin läntisiin, sopii hyvin latinalainen aakkosto, kun taas Aunuksessa puhuttuun livviin joudutaan lisäämään enemmän kirjainmerkkejä.

Perestroikan ajasta lähtien tuli mahdolliseksi julkaista kirjallisuutta karjalaksi, mikä oli omiaan vahvistamaan kielen asemaa. Toisaalta maaseudun rapistuminen ja kaupungistumisen kiihtyminen ovat vieneet kieleltä elinvoimaa, koska karjala on tyypillisesti ollut maaseudun kieli. Karjalan kieltä on pyritty elvyttämään, ja siihen on saatu apua Suomestakin. Kieleen on luotu ja luodaan jatkuvasti uusia sanoja merkitsemään uusia käsitteitä, mutta silti kielen ilmaisuvoimassa on puutteita.

Elvytyksen tulokset ovat olleet ristiriitaisia. Svetlana Kovaleva esittelee karjalaisten sosiolingvististä asemaa ja yhteiskunnan kehityksen vaikutusta kieleen. Karjalaisten osuus tasavallan väestöstä on vähentynyt tasavallan koko historian ajan ja tuoreimmassa väestönlaskennassa karjalaisia oli vain 9,2\% koko väestöstä. Karjalaisetkin ovat kaupungistuneet, mutta he ovat enemmistönä ainoastaan Aunuksen kaupungissa. Ajan myötä yhä pienempi osa karjalaisista puhuu karjalaa äidinkielenään, mikä merkitsee kielellistä venäläistymistä. Vuonna 2002 vajaa puolet karjalaisista osasi oman ilmoituksensa mukaan karjalaa. Karjalan kielellä on 1990-luvulta lähtien julkaistu sanomalehteä, muita lehtiä ja kirjallisuutta. Yhteisiä kirjakielen normeja ei ole kyetty murre-erojen vuoksi luomaan, mikä on antanut valtiovallalle verukkeen olla myöntämättä kielelle virallista asemaa.

Puhujien ja ympäristön asenne kieltä kohtaan on tärkeä kielen säilymisen kannalta. Sanna-Riikka Knuuttila on tutkinut karjalaisten asennetta omaan kieleensä. Karjalaisilla on oma järjestönsä Karjaląৃien kerähmö, joka pyrkii pitämään yllä karjalaisuutta. Keräbmö on järjestänyt kongresseiksi kutsuttuja kokoontumisia Karjalan tasavallassa suunnilleen joka neljäs vuosi. Kokouksissa on keskusteltu karjalan kielen asemasta ja keinoista pitää kieltä elossa. Koska kaikki karjalaisetkaan eivät puhu karjalaa, kongressien työkielenä on paradoksaalisesti ollut venäjä. Tässäkin näkyy karjalan kielen ristiriitainen asema: sitä arvostetaan mutta ei käytetä.

Karjalan kielen puhujia on myös Karjalan tasavallan ulkopuolella Tverissä. 1930-luvulla Tverin karjalaiset muodostivat enemmistön karjalaisista Neuvostoliitossa. Esa Anttikoski esittää artikkelissaan katsauksen kielipolitiikkaan Tverissä neuvostoaikana. Kieltä ja kansallista itsehallintoa Tverin karjalaisille kehitettiin paradoksaalisesti 1930-luvulla, joka yleisesti tunnetaan ideologisen kiristymisen vuosikymmenenä ja joka huipentui kansallisten älymystöjen tuhoamiseen vuosien 1936-1938 vainoissa. Kuitenkin Tveriin eli virallisesti Kalininin oblastïn muodostettiin Karjalainen kansallinen piiri vuonna 1937. Piirissä oli määrä ottaa käyttöön karjalan kirjakieli, jota 
Pekka Hakamies: Tekstien ja laulujen Karjala

kirjoitettiin kyrillisillä aakkosilla. Lopulta tveriläinen koulutettu väki joutui vainojen uhriksi 1938-1939 ja kansallinen piiri haudattiin hiljaa 1939.

\section{KARJALA TEKSTEISSÄ JA MUSIIKISSA}

Kokoelman alkuosan artikkelit käsittelevät kielipolitiikkaa ja karjalan kielen asemaa. Edempänä siirrytään tarkastelemaan, miten kauno- ja tietokirjallisuudessa, populaarikulttuurissa ja kansanmusiikissa on kuvattu Neuvosto-Karjalaa ja tuotettu karjalaisuutta. Tieto- ja populaarikirjoittelu oli lähellä propagandaa sikäli, että sen tehtävänä oli kuvata Neuvosto-Karjalaa osana neuvostoyhteiskuntaa, sen hyvää kehitystä ja valoisaa tulevaisuutta. Tämä tulee selvästi esiin Tuulikki Kurjen tarkastelussa, jonka kohteena on Jaakko Rugojevin Neuvosto-Karjalan näkymiä verrattuna muuhun vastaavaan kirjoitteluun. Raamit olivat melko tiukat ja karjalaisuus jäi koko lailla neuvostoideologian varjoon.

Mari Ristolaisen tutkimassa Sortavalan harrastajakirjallisuudessa neuvostoteema on myöhemmin korvautunut karjalaisuudella, kun ideologinen pohja mureni. Kirjoittelussa on esitetty Sortavala ensin neuvostoyhteiskunnan paikkana, ja myöhemmin siitä on tullut selvästi osa Karjalaa, kuitenkin pääasiassa venäläisestä näkökulmasta. Kotiseututyö, krajevedenije, on keskeinen termi Ristolaisen artikkelissa. Kiinnostus kotiseututyöhön on hänen mukaansa kasvanut aina murrosaikojen myötä, ja Neuvostoliiton hajoamista seurasi taas kerran tällainen kausi. "Sortavalan patriotismi" syntyi jo neuvostoaikana, jolloin ideologisesti sopivaa harrastajataidetta suosittiin, ja yhteiskunnan muutoksista huolimatta paikallisen hegemonian mukaista harrastustoimintaa on edelleen pyritty suosimaan.

Natalja Čikina ja Valentina Mironova käsittelevät artikkeleissaan karjalankielistä kirjallisuutta ennen kaikkea perestroikan ajalta alkaen, jolloin ruvettiin julkaisemaan suomen ohella myös karjalaksi kaunokirjallisuutta, ennen kaikkea runoja. Natalja Čikinan artikkelissa tulee esiin, miten karjalaiset kirjailijat tyypillisesti ottavat aiheensa ja motiivinsa omasta lähipiiristään, jolloin karjalaisuus tulee kielen ohella myös sisällön kautta näkyviin. Karjalankielinen kirjallisuus on 2000-luvulla saanut tukea sekä omasta tasavallasta että sen ulkopuolelta. Kirjallisuus on kuitenkin asemaltaan sidoksissa kieleen, minkä vuoksi levinneisyys ja elinpiiri ovat verraten suppeat.

Monet kirjailijat ovat syntyjään suvuista, joissa on ollut myös folkloren taitajia, ja karjalan kieli on elänyt ennen kaikkea maaseudulla, jossa myös perinteinen elämäntapa ja folklore ovat olleet lähellä. Sen vuoksi karjalaiseen kirjallisuuteen on tullut suhteellisen paljon folkloremotiiveja, joita Valentina Mironova tarkastelee artikkelissaan erityisesti aunukselaisen Vladimir Brendojevin runoissa.

Olga Iljuhan ja Jurij Šikalovin artikkelin aiheena on monimerkityksinen venäjän kielen sana rodina, joka merkitsee yhtäältä synnyinseutua ja kotiseutua toisaalta isänmaata. Toisinaan termiä voidaan tarkentaa puhumalla suuresta ja pienestä rodinasta. Konkreettisena aineistona tarkastelussa ovat Neuvosto-Karjalan suomen kielen oppikirjat 1920-1940-luvuilla. Oppikirjoilla oli myös ideologinen kasvatuksellinen tehtävä, joten niiden perusteella voidaan tutkia tuon ajan koululaitoksen arvomaailmaa. Ideologinen kasvatus ja neuvostovaltio johtajineen tulivat yhä näkyvämmin esille 1930-luvulla ja 
siten "suuri kotimaa" sai lisää merkitystä, kun kaksikymmentäluvulla "pieni kotimaa" eli paikallisuus oli ollut keskeisellä sijalla.

Pekka Suutari pohtii artikkelissaan sitä, mitä oikein representoitiin, kun karjalaista kansanmusiikkia esitettiin. Hän jakaa neuvostoajan musiikin harrastuksen kolmeen ryhmään: klassiseen taidemusiikkiin, valtion folkloreyhtyeisiin ja harrastajakuoroihin. Tarkastelun aikaväli on 1930-1960-luku. Klassisessa taidemusiikissa kansanperinteen ja erityisesti Kalevalan aiheet tulivat esille erityisesti Petroskoissa työskennelleiden säveltäjien tuotannossa ja valtion kansanmusiikkiyhtyeenä oli tietysti Kantele. Harrastajakuoroja syntyi runsaasti varsinkin 1930-luvulla, ja valtio piti niistä hyvää huolta. Musiikkikulttuurin yleisilme oli venäläinen ja karjalaisuutta voi nähdä vain toisinaan antamassa paikallisväriä siitäkin huolimatta, että päällisin puolin karjalaisuutta korostettiin.

Elina Niiranen tarkastelee yhden vienalaisen 1900-luvulla eläneen laulajan repertuaaria. Kulttuurielämä muuttui Karjalan kylissä syvällisesti 1920-luvulta alkaen, kun spontaanin harrastuksen tilalle tuli organisoitu ja ohjattu toiminta. Vienan tiiviit kontaktit Suomeen ennen vallankumousta näkyvät siinä, että suomalaistyyppisistä rekilauluista tuli merkittävä osa uudempaa vienalaista lauluperinnettä. Niirasen artikkelissa keskeistä on se, miten vienalainen kansanlaulaja Maria Fedorova on itse kuvannut laulujaan. Laulut liittyivät hänen mielessään elämän eri vaiheisiin, ja sisältö oli tärkeä ryhmittelyn peruste. Fedorovan suhde lauluihinsa kuvastaa laajemminkin sitä, miten keskeistä lauluperinne oli karjalaisten kylien elämässä vielä 1900-luvulla.

\section{KARJALA PAIKKANA}

Teoksen kaksi viimeistä artikkelia ovat muita etäämmällä teoksen pääkohteesta, Neuvosto-Karjalasta: Natalia Baschmakoff käsittelee venäläisen kirjallisuuden tapaa kuvata Karjalan kannasta 1900-luvun vaihteessa ja Seppo Knuuttilan aiheena on pohjoiskarjalainen kylätutkimus. Kummassakin artikkelissa tarkastellaan paikan ja paikallisuuden kokemista ja siitä kertomista. Molemmissa artikkeleissa myös pohditaan näitä käsitteitä enemmän kuin muissa, joissa taas empiiriset aineistot ja havainnot ovat etusijalla. Baschmakoff perustaa kirjoituksensa paljolti venäläisten kulttuurintutkijoiden kirjoituksiin ja Knuuttila tukeutuu kulttuurimaantieteilijöiden teoksiin. Knuuttilan artikkeli on samalla lyhyt katsaus paikallisuuden tutkimukseen ja kotiseutukirjallisuuteen Suomessa, ja kansainvälisenä vertailukohtana hänellä on Henry Glassien tutkima Ballymenonen kylä Pohjois-Irlannissa.

Kokonaisuutena teoksen artikkelit tuovat esiin rajantakaisen Karjalan ja karjalaisten historian kaikessa ristiriitaisuudessaan 1900-luvulla, kun tasavallan nimikkokansan oma kieli ja kulttuuri ovat jääneet milloin suomen, milloin venäjän kielen ja kulttuurin varjoon. Karjalaisuus ja paikallisuus ovat useimmiten olleet välineinä muihin tavoitteisiin pääsemiseksi, ja tavoitteet on viime kädessä määritelty muualla kuin Karjalassa.

Pekka Hakamies on folkloristiikan professori Turun yliopistossa. Hän on aikaisemmin työskennellyt pitkään Karjalan tutkimuslaitoksessa Joensuun yliopistossa. 